\title{
Development of a Clinical Protocol for Hepatic Gene Transfer: Lessons Learned in Preclinical Studies ${ }^{1}$
}

\author{
FRED D. LEDLEY, R. MARK ADAMS, HUMBERTO E. SORIANO, GRETCHEN DARLINGTON, \\ MILTON FINEGOLD, ROBERT LANFORD, DEE CAREY, DOROTHY LEWIS, PATRICIA A. BALEY, \\ STEVE ROTHENBERG, MARK KAY, MARY BRANDT, ROBERT MOEN, W. FRENCH ANDERSON. \\ PETER WHITINGTON, WILLIAM POKORNY, AND SAVIO L. C. WOO

\begin{abstract}
Departments of Cell Biology [F.D.L., R.M.A., S.L.C.W.], Pediatrics [F.D.L., H.E.S., M.F.], Pathology [G.D. M.F., P.A.B.], Surgery [S.R., M.B., W.P.], Molecular Genetics [M.K., S.L.C.W.], and Microbiology and Research [R.L., D.C.], San Antonio, Texas 78228; Department of Pediatrics [P.W.], University of Chicago, Chicago, Illinois 60639; Genetic Therapy Incorporated [R.M.], Gaithersburg, Maryland 20878; and National Institutes of Health [W.F.A.]. Bethesda, Maryland 20892
\end{abstract} \\ Immunology [D.L.], Baylor College of Medicine. Houston, Texas 77030; Southwest Foundation for Biomedical
}

\begin{abstract}
Strategies for hepatic gene therapy have been proposed that involve isolation of primary hepatocytes and introduction of recombinant genes into these cells in culture, followed by autologous hepatocellular transplantation (HCT). Consideration of clinical applications requires data suggesting that HCT can be performed safely in human subjects in addition to data indicating that recombinant gene expression can reverse a disease process. This report describes preclinical studies that underlie a clinical trial of HCT in which hepatocytes would be labeled with a marker gene to facilitate assessment of engraftment in the recipient. Human hepatocytes were harvested from liver segments preserved in Belzar's solution and transduced with an amphotropic retroviral vector carrying a recombinant marker gene (neomycin phosphotransferase II). Human hepatocytes were recovered from monolayer culture, stained with the fluorescent dye $1,1^{\prime}$-dioctadecyl-3,3,3,3' tetra-methylindo-carbocyanine perchlorate (DiI) and transplanted into severe combined immunodeficient mice by splenic injection. Engrafted hepatocytes were identified in the liver and spleen of severe combined immunodeficient mice but not immunocompetent controls. Two large animal models of HCT are described. In a dog model, neomycin phosphotransferase II-containing hepatocytes were identified in the liver $7 \mathrm{wk}$ after transplantation. In a baboon model, autologous HCT with DiI-stained cells demonstrated that transplanted cells assume a normal morphology and constitute up to $5 \%$ of hepatocytes. These data demonstrate transduction and transplantation of human hepatocytes and the feasibility of HCT in large animals.
\end{abstract}

Received April 30, 1992; accepted September 14, 1992.

Correspondence and reprint requests: Dr. Fred Ledley, Department of Cell Biology, Baylor College of Medicine, One Baylor Plaza, Houston, TX 77030.

Supported by grants NIH-1P30-HD-27823, NIH-P30-HD-24064, NIH-PO1DK-44080, the NIDDK Liver Tissue Procurement and Distribution System, and the ACTA foundation. R. M. A. has a predoctoral graduate research fellowship from the March of Dimes Birth Defects Foundation (no. 18-FY91-0989). F. D. L. is an Assistant Investigator and S. L. C. W. is an Investigator of the Howard Hughes Medical Institute. F. D. L. and S. L. C. W. have equity interest in GeneMedicine. Inc.

'These data were described in public hearings of the Human Gene Therapy Subcommittee or Recombinant DNA Advisory Committee in support of a protocol entitled "Hepatocellular Transplantation in Acute Hepatic Failure and Targeting Genetic Markers in Hepatic Cells." Portions of this work have been reported Genetic Markers in Hepatic Cells." Portions of this work have been reported
previously in Kay MA, Baley P, Rothenberg S, Leland F. Fleming L. Ponder KP. Liu T. Finegold M. Darlington G. Pokorny W, Woo SLC: Proc Natl Acad Sci USA 89:89-93, 1989 and Adams RM. Soriano-Brucher HE. Wang M. Darlington GJ, Steffen D, Ledley FD: Proc Natl Acad Sci USA (in press)
On the basis of these studies, the proposed clinical trial for gene transfer and transplantation in human subjects has been approved by the National Institutes of Health and the Food and Drug Administration. These studies illustrate the nature and extent of preclinical data required to gain approval for clinical trials involving gene transfer into human subjects. These data also illustrate the limitations of existing methods that may be used for hepatic gene therapy in the future. (Pediatr Res 33: 313-320, 1993)

\section{Abbreviations}

HCT, hepatocellular transplantation AAT, $\alpha_{1}$-antitrypsin

DiI, 1,1'-dioctadecyl-3,3,3,3'-tetra-methylindo-carbocyanine perchlorate; $\mathrm{DiI}-\mathrm{C}_{18^{-}}(\mathbf{3})$

SCID, severe combined immunodeficient

NEO-R, neomycin phosphotransferase II, neomycin resistance gene

OLT, orthotopic liver transplantation

PCR, polymerase chain reaction

NIH, National Institutes of Health

$\beta$-gal, $\beta$-galactosidase

The potential for somatic gene therapy is based on methods for gene transfer in which recombinant genes are introduced into somatic cells to reconstitute expression of a genetically defective gene or constitute expression of a novel therapeutic gene (1-3). One strategy for somatic gene therapy involves harvesting primary cells from a patient, growing these cells in culture, transducing these cells ex vivo with a vector containing a recombinant gene, and returning these cells to the patient by autologous transplantation.

With the initiation of clinical trials at the NIH involving gene delivery into patients after ex vivo gene transfer of autologous lymphocyte populations, it is now possible to realistically consider the development of clinical trials for other approaches to gene therapy. Such clinical trials must be based on data that indicate not only that gene transfer can be performed in a safe and efficient manner but also that the clinical and surgical procedures required for gene delivery are themselves feasible and efficacious. For example, the clinical application of ex vivo gene 
therapy to hepatic diseases requires not only the demonstration that genes can be introduced into primary hepatocytes in culture (4-8) but also the ability to perform HCT, a procedure that has never been performed in human subjects (9).

Research in our laboratories has been directed at developing methods for hepatic gene therapy. Perhaps the most difficult aspect of this research has been establishing the feasibility of HCT. There is extensive literature on animal experiments that suggests that HCT can be performed successfully in small animal models $(10,11)$. Nevertheless, there remains considerable uncertainty about the feasibility of HCT. One of the reasons HCT has not been more widely accepted is that many early animal studies were not able to unequivocally demonstrate the location and number of engrafted cells after transplantation. Heterotopic engraftment of hepatocytes has been demonstrated in the peritoneum, portal vein, spleen, fat pads, pancreas, or dorsal fascia, where the characteristic morphology of hepatocytes is recognizable by conventional histologic techniques (10, 11). Recent studies have used transgenic mice containing recombinant genetic markers to demonstrate engraftment of hepatocytes within the hepatic parenchyma after intraportal or intrasplenic injection. Ponder et al. (9) described a mouse model in which donor cells from a transgenic mouse expressing human AAT and Escherichia coli $\beta$-galactosidase were transplanted into syngeneic recipients. These studies demonstrated that, after transplantation, human AAT could be detected in the recipient's serum and that cells expressing $E$. coli $\beta$-galactosidase could be identified within the hepatic parenchyma for the lifetime of the animal (8). Similar results have been reported by Gupta et al. $(12,13)$, who used hepatocytes from a transgenic mouse that expressed the hepatitis B surface antigen. Another small animal model for HCT is the Watanabe rabbit, which is deficient in the LDL receptor. Transplantation of hepatocytes genetically modified to express recombinant human or rabbit LDL receptor has been shown to result in intrahepatic engraftment and fractional lowering of serum cholesterol $(14,15)$.

To assess the feasibility of HCT in human subjects and establish a clinical foundation for future experiments involving hepatic gene therapy, we have proposed a phase I clinical trial of HCT in children with life-threatening hepatic insufficiency who have no other medical or surgical options. Heterologous HCT represents a potentially important therapeutic modality that, by itself, may have applications in the treatment of hepatic insufficiency, especially in children, for whom there is a chronic shortage of donor organs and a 20 to $50 \%$ mortality rate (16-20). In experimental animals, HCT has been shown to improve survival in hepatic failure in mice or dogs induced by N-galactosamine, dimethylnitrosamine, or surgery (21-28). Our expectation is that HCT may provide short-term hepatic support for patients awaiting OLT, a "bridge to recovery" for patients with infectious hepatitis, or a long-term repopulation of the patient's liver with healthy donor cells (29).

To rigorously evaluate the success of hepatocellular engraftment, we proposed introducing a recombinant marker gene, NEO-R, into hepatocytes by transduction with a retroviral vector (LNL6) before transplantation. The presence of this genetic marker in transplanted cells will enable a quantitative determination of the number of cells engrafting in the liver and their persistence.

There continues to be controversy concerning the propriety of clinical trials involving gene transfer as well as the extent and nature of in vitro and animal studies that should be performed before clinical trials should begin. This report describes the preclinical data, concerning gene transfer into human hepatocytes and HCT in animal models, that were submitted to the Human Gene Therapy Subcommittee, Recombinant Advisory Committee, Director of the NIH, and Food and Drug Administration in support of our proposed clinical trial. This report is intended both to demonstrate the capabilities and limitations of current technologies for ex vivo hepatic gene therapy and to illustrate the nature and extent of preclinical studies that led to approval for a clinical trial involving gene transfer into the liver of human subjects (Federal Register, July 18, 1991).

\section{METHODS AND RESULTS}

Harvest and cultivation of human hepatocytes. Human liver segments preserved in UW solution (30) were made available by the "Liver Tissue Procurement and Distribution System" (31). Hepatocytes were harvested from the right lobes of the liver that were available after reduced OLT or from organs that had evidence of anoxia, which made them unsuitable for OLT. Hepatocytes were isolated using variations of procedures described previously $(9,32,33)$. Liver segments were perfused sequentially with EDTA solution (Earle's balanced salt solution without $\mathrm{Ca}^{++}, \mathrm{Mg}^{++}+0.5 \mathrm{mM}$ EDTA) followed by collagenase solution [Earle's balanced salt solution with $\mathrm{Ca}^{++}, \mathrm{Mg}^{++}, 180$ $\mathrm{mg} / 400 \mathrm{~mL}$ collagenase B (Boehringer Mannheim, Mannheim, Germany), $8 \mathrm{mg} / 400 \mathrm{~mL}$ soybean trypsin inhibitor] for $15 \mathrm{~min}$ each at $37^{\circ} \mathrm{C}$. Hepatocytes were then physically separated by gentle shaking in collagenase solution, filtered through sterile gauze, washed, and plated on Primaria plates at densities of $2 \times$ $10^{4} / \mathrm{cm}^{2}$ in media with $10 \%$ serum (34). After 8 to $24 \mathrm{~h}$, medium was replaced with a hormonally defined medium (SUM-Chowdhury), similar to those used previously to maintain the state of differentiation and the proliferation potential of mature hepatocytes (33-35) but adapted to optimize the morphology of human hepatocytes [SUM-Chowdhury medium: 3:1, minimum essential medium: weymouths (tyrosine-free), insulin, $1.7 \times 10^{-8} \mathrm{M}(100$ $\mathrm{ng} / \mathrm{mL})$; glucagon, $2.8 \times 10^{-7} \mathrm{M}(1 \mu \mathrm{g} / \mathrm{mL})$; epidermal growth factor, $8.3 \times 10^{-9} \mathrm{M}(50 \mathrm{ng} / \mathrm{mL})$; somatotropin, $9.5 \times 10^{-11} \mathrm{M}$ $(10 \mu \mathrm{U} / \mathrm{mL})$; linoleic acid, $1.8 \times 10^{-5} \mathrm{M}(5 \mu \mathrm{g} / \mathrm{mL})$; selenium, 3 $\mathrm{nM} ; N$-2-hydroxyethylpiperazine- $N^{\prime}$-2-ethanesulfonic acid $(\mathrm{pH}$ 7.4), $10 \mathrm{mM}$; dexamethasone, $10^{-7} \mathrm{M}$; thyroxine, $1 \mu \mathrm{M}$; transferrin, $1.3 \times 10^{-7} \mathrm{M}(10 \mu \mathrm{g} / \mathrm{mL})$; Gly-His-Lys, $6.5 \times 10^{-8} \mathrm{M}(20$ $\mathrm{ng} / \mathrm{mL})]$. Tyrosine-free medium was used to select against the proliferation of fibroblasts, endothelial cells, or dedifferentiated hepatocytes that might lose expression on phenylalanine hydroxylase.

Hepatocytes were harvested from 18 livers. Hepatocyte yields from appropriately preserved and histologically normal livers ranged from 2.7 to $10 \times 10^{6} / \mathrm{g}$ with 75 to $95 \%$ viability by trypan blue exclusion and plating efficiencies of 60 to $90 \%$. Cells surviving in this culture medium exhibited the morphology of hepatocytes, and cells plated at a density of $4 \times 10^{4}$ cells $/ \mathrm{cm}^{2}$ grew to confluence within $4 \mathrm{~d}$ in tyrosine-free, hormonally defined medium (34). Immunohistochemical staining for AAT or glutamine synthase demonstrated that $>99 \%$ of the cells in culture express these liver-specific products (34). Extremely poor yields were obtained from livers with evidence of fatty infiltration or inadequate preservation.

These experiments demonstrated that human hepatocytes could be isolated from liver samples procured under clinically applicable conditions, proliferated in hormonally defined media, and still preserve properties characteristic of differentiated hepatocytes.

Retroviral transduction. The LNL6 vector containing the $E$ coli NEO-R gene and a cell line, LNL6/PA317/c8, producing amphotropic LNL6, were constructed by Dr. Dusty Miller in the PA317 cell line $(36,37)$. Frozen lots of supernatant from this cell line, certified for clinical applications, were provided by Genetic Therapy Inc., Gaithersburg, MD. A vector containing the $E$. coli $\beta$-gal gene (zen- $\beta$-gal) was provided by Dr. Philippe Soriano (Baylor College of Medicine). Hepatocytes were transduced by replacing the culture media with a 1:1 dilution of serum-free media:retroviral supernatant with $8 \mu \mathrm{g} / \mathrm{mL}$ polybrene between 24 and $72 \mathrm{~h}$ after harvest. Cells were maintained in hormonally defined, tyrosine-free media for $8 \mathrm{~d}$ after transduction (10 d after harvest) before analysis was performed.

Hepatocytes transduced with the $\beta$-gal-containing vectors were 
identified by histochemical staining with X-gal [5-bromo-4chloro-3-indolyl B-D-galactopyranoside (Boehringer Mannheim)] and exhibited the same morphology as hepatocytes on control plates expressing AAT and glutamine synthase (34). This experiment demonstrated that the amphotropic vector was capable of transducing differentiated human hepatocytes. The efficiency of transduction with LNL6 was assessed by semiquantitative analysis of the NEO-R provirus by PCR in purified genomic DNA using the scheme described by Morgan et al. (38) and Adams et al. (34). This assay is capable of detecting a single integrated provirus in $10^{5}$ cells $(34,38)$. Experiments using six different human livers (Fig. $1 \mathrm{~A}$ ) demonstrate that each sample was successfully transduced with the LNL6 vector. A semiquantitative standard was established by amplification of NEO-R from a transgenic mouse containing two copies of the Tn7 NEO$\mathrm{R} /$ diploid genome (Fig. 1A). Because there is substantial variation in the absolute amount of PCR product in different experiments, control curves are run coincident with all experiments to make semiquantitative determinations of proviral number in cultures of transduced cells. As a control, PCR is performed with a set of primers that recognize the MUT locus to rule out variations in the quality or amount of the DNA template. Comparison of experimental samples with the standard curve indicates that the efficiency of transduction was 1 to $3 \%$. This efficiency was 10 -fold lower than the efficiency in parallel experiments using mouse hepatocytes (Fig. 1A). Transduction of human hepatocytes has also been described by Grossman et al. (39).

\section{A}

\section{$M 123456$ A B C DEF GHM}
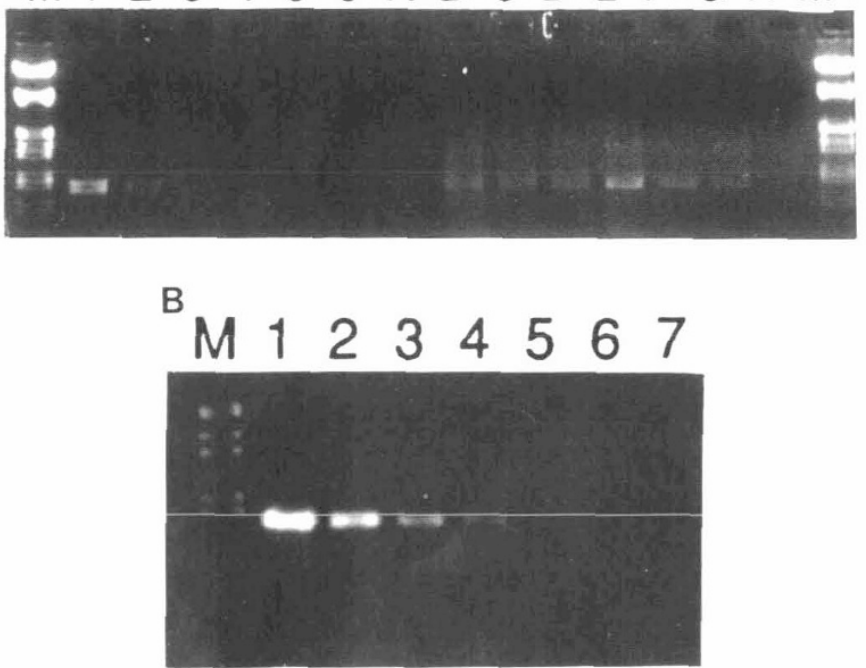

Fig. 1. Transduction of human hepatocytes with amphotropic LNL6 retroviral vector. $A$, The transduction hepatocytes from seven human livers (lanes $A-G$ ) were transduced with the LNL6 vector, and the integrated provirus identified by PCR $10 \mathrm{~d}$ after transduction. As a semiquantitative control, DNA from a transgenic mouse containing two copies of NEO-R sequences in each cell was analyzed by PCR after serial 10-fold dilutions of this DNA with nontransduced DNA. Lane $1,10^{\prime}$ dilution; lane 2, $10^{2}$ dilution; lane $3,10^{3}$ dilution; lane $4,10^{4}$ dilution: lane $5,10^{5}$; and lane $6,10^{6}$ dilution. Negative controls included nontransduced human DNA (lane H). M, molecular weight markers (HindIII/ EcoRI lambda). B, To demonstrate the feasibility of detecting proviral sequences in transduced hepatocytes after transplantation of these cells into normal hosts. DNA from a transduced human liver specimen was diluted with nontransduced DNA and PCR was performed. Lane 1, transduced human hepatocyte DNA; lane 2, 1:3 dilution; lane 3, 1:10 dilution; lane 4, 1:30 dilution; lane 5, 1:100 dilution; lane 6, 1:300 dilution; and lane 7, 1:1000. The detection of recombinant material in human hepatocytes diluted 1:300 suggests that this signal would be detectable with transplants that constitute $0.3 \%$ of host hepatocytes.
After HCT, the transplanted cells will constitute only a fraction of the recipient's liver. To demonstrate that methods for PCR detection of the proviral sequences were sufficiently sensitive to detect these sequences after transplantation, DNA from the transduced hepatocytes was diluted with nontransduced DNA (Fig. $1 B$ ) and analyzed by PCR. Proviral sequences were detected at a 1:300 dilution, indicating that this method could detect engraftment constituting as little as $0.3 \%$ of cells in the liver.

Transplantation of human cells in SCID and immunocompetent mice. Heterotopic transplantation of human hepatocytes has been described previously in athymic rats (40) and nude mice (41). To demonstrate that human hepatocytes recovered from culture by trypsinization were viable and capable of engrafting in the liver, transplants were performed with human cells in immunodeficient (SCID) or normal C57/BL-6 mice. In these experiments, the human hepatocytes were stained with the fluorescent dye DiI, which enables detection of transplanted cells in the recipient organ by fluorescence microscopy. This dye was originally developed for research in neurobiology, where it has been shown not to metabolize and does not exchange between cells. We have described optimal conditions for in vitro staining of hepatocytes with DiI and evidence that this dye remains localized to transplanted cells in vitro and after HCT in congenic animals $(42,43)$.

Human hepatocytes in culture were stained by addition of 2.7 $\times 10^{-5} \mathrm{M}$ DiI $(25 \mu \mathrm{g} / \mathrm{mL})+1 \%$ DMSO for $30 \mathrm{~min}$, trypsinized, and washed, and $2 \times 10^{6}$ cells were infused into the spleen of normal or SCID animals. Animals were killed at 5 or $12 \mathrm{~d}$ after transplantation. All of the animals survived the transplant procedure. Three of six animals had areas of scarring in the liver as seen by gross examination, possibly due to infarction. Complete necropsy revealed no other significant abnormalities. Histologic examination of the liver in transplanted SCID animals showed normal architecture. Fluorescent hepatocytes could be identified in the liver (Fig. 2A) and spleen (Fig. 2B) by their large size, polygonal shape, and prominent nuclei. Fluorescent material was also observed in smaller cells presumed to be phagocytotic cells that had ingested fluorescent debris. Histologic examination of the liver in immunocompetent controls, transplanted with human hepatocytes, showed no evidence of fluorescent hepatocytes, although reticuloendothelial cells contained fluorescent material (Fig. 2C).

These experiments indicate that human hepatocytes are viable and remain capable of engrafting within the hepatic parenchyma after cultivation and trypsinization. The lack of significant adverse events in immunodeficient animals also indicates that these procedures can be performed without infectious complications.

The efficiency of HCT in murine models. The clinical impact of HCT will be critically dependent upon the fraction of the host liver that can be constituted from the hepatocellular graft. In the murine model of Ponder et al. (9), two methods were used to estimate the number of transgenic hepatocytes engrafted in the liver. One estimate was based on the level of human AAT present in the serum of donor and recipient animals. This calculation places the fraction of engrafted cells at ranges from $10^{-2}$ to $6 \times$ $10^{-4}(9)$. The second estimate, based on the number of cells expressing $E$. coli $\beta$-gal on histochemical analysis, is complicated by the fact that in the donor mouse liver only $10 \%$ of cells express this transgene. The number of cells in the recipient that exhibit $\beta$-gal staining ranges from $3 \times 10^{-4}$ to $5 \times 10^{-5}$. If this number is corrected for the fraction of cells expressing this gene in the donors, then the fraction of engrafted cells is in the range of $3 \times$ $10^{-3}$ to $5 \times 10^{-4}$, which is concordant with the estimate made from the AAT data. It should be noted that this fraction is roughly consistent with the number of fluorescent cells observed after transplantation of human hepatocytes in SCID mice.

A similar efficiency of engraftment was apparent in experiments performed using syngeneic cells transduced with the LNL6 retroviral vector (Fig. $3 A$ ). In these experiments, cells were harvested, cultivated, transduced, and transplanted using the pro- 

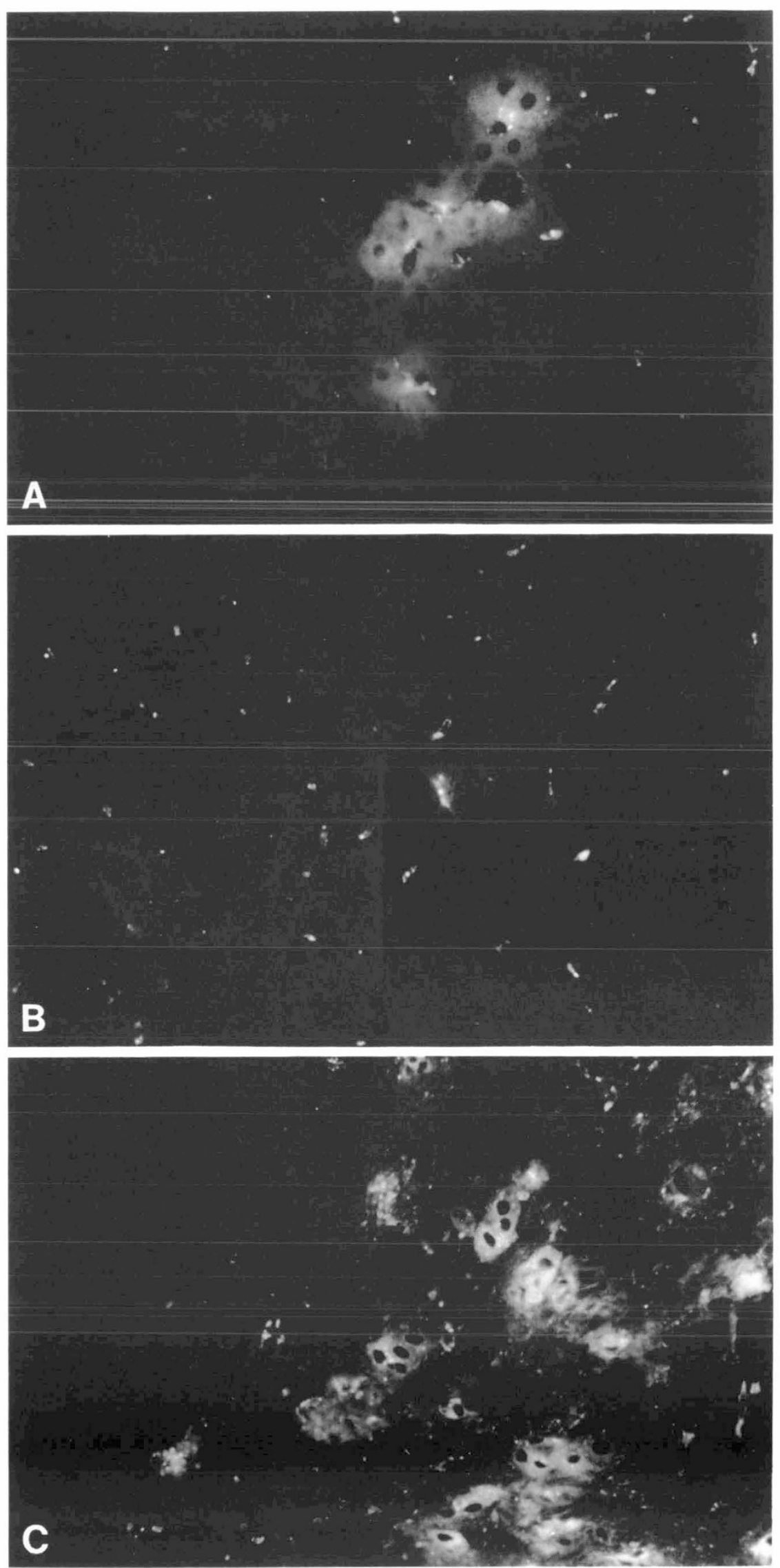

Fig. 2. Transplantation of human hepatocytes into SCID mice and immunocompetent controls. Human hepatocytes stained with DiI in culture were trypsinized and transplanted into the spleen of SCID or normal control mice and analyzed $14 \mathrm{~d}$ after transplant. Histologic analysis of livers after transplantation was normal. Fluorescent cells with the morphology of hepatocytes were evident in the livers of SCID mice primarily adjacent to portal vessels $(A)$ but were not seen in normal controls $(B)$. Fluorescent hepatocytes were also apparent in the spleen at the site of injection $(C)$. 
A

\section{A B C D 12}

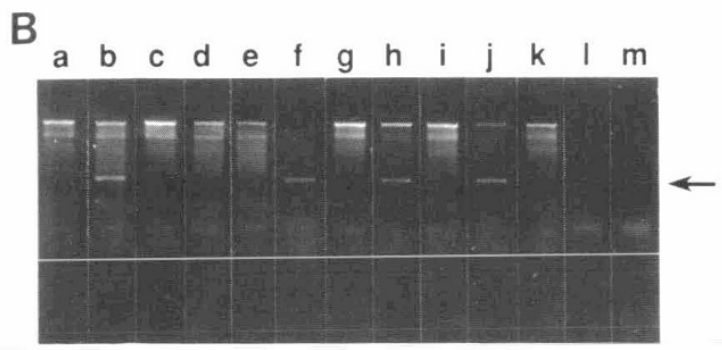

a b c d e f g h i j k l m

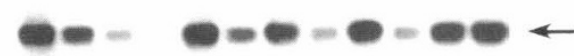

tion of dog hepatocytes with an amphotropic vector carrying both NEO-R and human AAT. Expression of human AAT was observed for several weeks after HCT and then was lost. PCR analysis of the liver from transplanted animals harvested $47 \mathrm{~d}$ after transplantation demonstrated that the recombinant provirus was evident in these samples (Fig. $3 B$ ), indicating that viable cells remained in the liver even though there was no expression from the recombinant provirus (44).

The feasibility of HCT and intrahepatic engraftment was also studied in two baboons. For this experiment, a left-lateral partial hepatectomy was performed, and hepatocytes were isolated, stained with DiI, and injected into the spleen. One wk later, the animals were killed. Histologic examination showed normal architecture in the liver, with no evidence for a distinct population of transplanted cells (data not shown). Rare sections had evidence of transplanted material within distal portal venule, with no evidence of infarctions (Fig. 4A). Fluorescent cells were seen throughout the hepatic parenchyma in two animals studied (Fig. 4B). Histologic examination of the spleen showed hepatocytes (Fig. $4 C$ ) that retained the fluorescent dye (Fig. 4D). To quantify the number of donor cells in the liver, hepatocytes were isolated and fluorescent and nonfluorescent cells counted in digitized phase contrast and fluorescent images from one animal (Fig. $4 E$, Table 1). These data demonstrate that $4.9 \%$ of the cells in the animal that underwent transplantation exhibited the fluorescence of the donor cells, a quantitative fraction consistent with qualitative observations by fluorescent microscopy of histologic sections. It should be noted that Kupffer cells are not present in significant numbers in this fraction of semipurified hepatocytes.

These experiments in large animals demonstrate the technical feasibility of handling large numbers of hepatocytes and safely injecting these cells into animals. HCT was also shown to constitute up to $5 \%$ of the hepatocytes in the liver from donor cells, a portion that is $>10$-fold greater than that observed in murine experiments.

\section{DISCUSSION}

Fig. 3. Identification of Neo- $\mathrm{R}$ in transduced and transplanted hepatocytes in murine and canine models. $A$. Genomic DNA was isolated from the liver of mice after transplantation with hepatocytes transduced with the LNL6 retroviral vector. Proviral sequences in engrafted cells was detected by PCR in two samples from one animal (lanes $A$ and $B$ ) but not a second animal (lanes $C$ and $D$ ). Lanes 1, 2, and 3 show mouse hepatocytes transduced with LNL6 before transplantation. $B$, Genomic DNA was isolated from various portions of the liver $47 \mathrm{~d}$ after transplantation of hepatocytes transduced with an amphotropic retroviral vector containing the NEO-R gene and human AAT. The NEO-R provirus was identified by PCR. Top. Ethidium bromide staining of the amplified PCR products; bottom, autoradiogram of the DNA blot hybridized with a NEO-R probe. $a$, Water control; $b$, nontransduced canine DNA: $c-f$, DNA from hepatocytes after transduction diluted with normal canine DNA $10^{-2}(c), 10^{-3}(d), 10^{-4}(e), 10^{-5}(f) ; g$, hepatocytes from an animal that underwent transplantation harvested $47 \mathrm{~d}$ after transplantation: $h-j$. liver tissue from different lobes harvested $47 \mathrm{~d}$ after transplantation. Data from Kay et al. (44).

cedure of Ponder et al. (9). The fraction of cells in the recipient liver that contained the provirus, as estimated by PCR, was in the range of $10^{-5}$. This was consistent with a transduction efficiency of 1 to $10 \%$ of cells and constitution of 0.05 to $0.1 \%$.

Large animal models of HCT. Significantly, different transplantation efficiencies were observed in two large animal models of HCT. Kay et al. (44) have explored several experimental approaches to HCT, including infusion into the spleen, superior mesenteric, or portal veins. These studies demonstrate that it is possible to transplant $10^{9}$ hepatocytes safely into $5-\mathrm{kg}$ dogs. These studies also demonstrate that it is possible to safely and effectively scale-up methods for hepatocellular harvest, transduction, and transplantation. The work of Kay et al. (44) involved transduc-
Somatic gene therapy for many disorders may require replacement of gene functions in the liver $(1,45)$. This is particularly true of inborn errors of metabolism that may require replacement of defective genetic functions in cells that contain cofactors, heterologous subunits, or substrates that are essential for activity of the gene product (46). Considerable progress has been made toward this goal with the development of methods for hepatocellular cultivation, transduction, and transplantation in small animal models (2-9, 12-15).

One premise of our approach to hepatic gene therapy is that the clinical feasibility of HCT needs to be established in clinical practice before it is applied in clinical trials of ex vivo hepatic gene therapy. To this end, we have proposed a clinical trial of hepatocellular transplantation to assess the feasibility in human subjects (29). In this clinical trial, we propose to mark allogenic hepatocytes with the LNL6 vector before transplantation and use the presence of this marker gene in the recipient organ to determine the number and location of engrafted cells. Societal and scientific concern about the propriety of clinical trials involving gene transfer led to the creation of a special process of ethical and scientific review of such trials. Proposed clinical trials of gene transfer are subject to review by the Human Gene Therapy Subcommittee, the Recombinant DNA Advisory Committee, and the director of the $\mathrm{NIH}$, in addition to local Institutional Review Boards, Institutional Biosafety Committees, and the Food and Drug Administration.

Three general questions were posed by these committees in considering our proposal: "Is it safe?" "Is it feasible?" "Is it necessary?" (47). These are the same questions that the scientific and medical community must ask in assessing whether clinical trials involving gene transfer are appropriate or whether such 

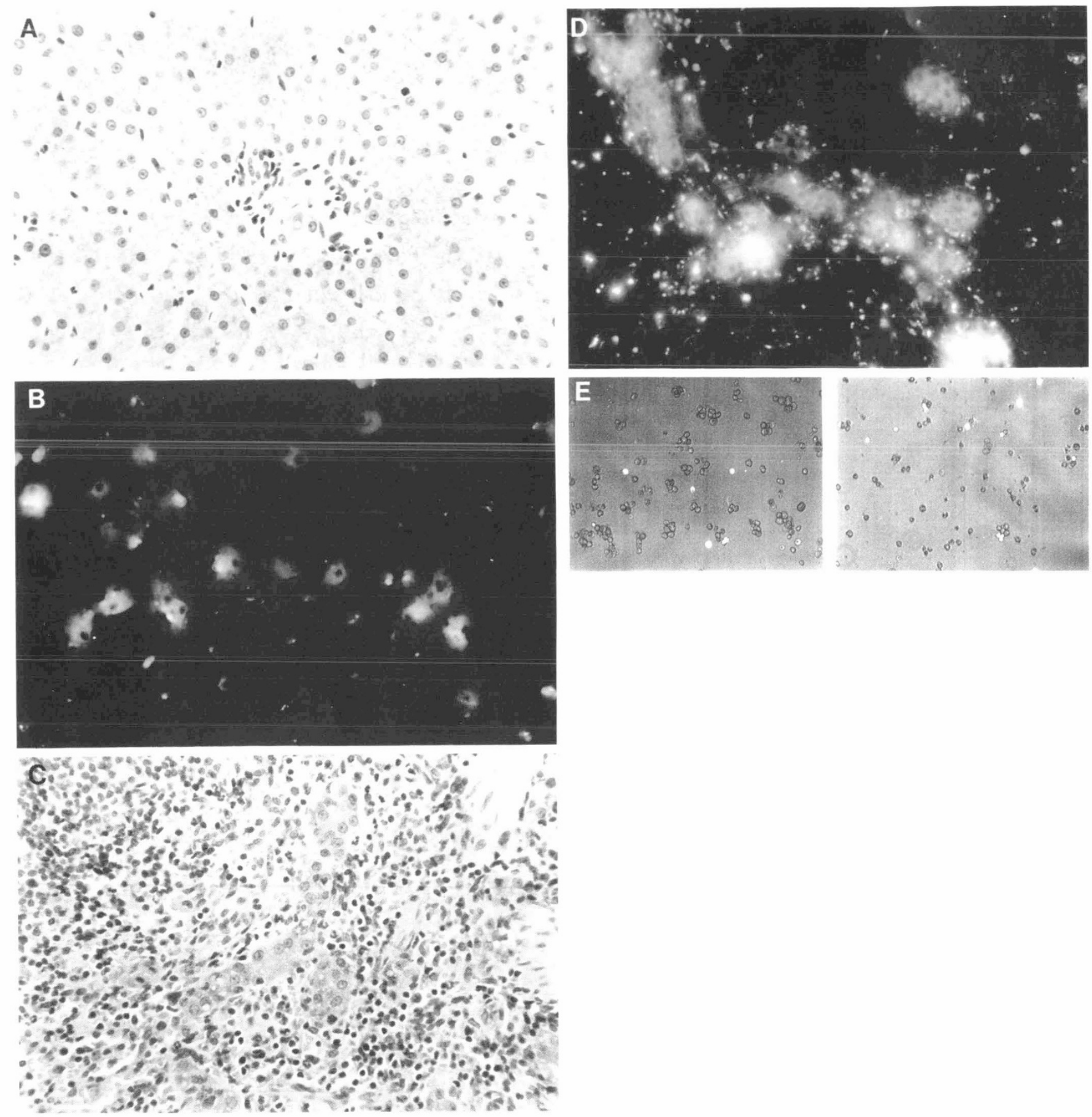

Fig. 4. Autologous HCT in the baboon. Autologous HCT was performed in a baboon by intrasplenic injection after partial hepatectomy, hepatocyte isolation, and staining of cells with DiI. Conventional histologic analysis was essentially normal with rare emboli identified in distal portal venule in two of 13 regions of the liver studied $(A)$. Fluorescent microscopy of the liver demonstrated stained cells derived from the graft throughout the liver $(B)$. Histologic examination of the spleen identified hepatocytes $(C)$ that contained the fluorescent dye $(D)$. Hepatocytes were harvested from the transplanted liver and fluorescent and nonfluorescent cells counted in superimposed digital images $(E)$. These data indicated that $4.9 \%$ of hepatocytes in the animal that underwent HCT arose from the hepatocellular graft.

Table 1. Counts of fluorescent (donor) hepatocytes and total hepatocytes identified by phase-contrast microscopy in hepatocytes prepared from baboon liver $7 d$ after transplantation of DiI-labeled, autologous cells

\begin{tabular}{lcc}
\hline & Counts/field (range) & Total \\
\hline Total cells & $170(142-248)$ & 842 \\
Fluorescent cells & $42(5-13)$ & 42 \\
$\%$ Donor cells & $(4-6 \%)$ & $4.9 \%$ \\
\hline
\end{tabular}

clinical research remains premature. The preclinical data described in this report were generated largely for this review process to answer these questions.

Is it safe? The safety of recombinant retroviral vectors has been assessed extensively in nonhuman primates $(48-51)$. The injection of both infectious and defective retroviral particles into experimental animals, under a variety of conditions (including cyclosporin-treated animals), has revealed no evidence of complications. The initial clinical studies of gene transfer in human subjects by Rosenberg et al. (52) also indicates that these vectors 
can be used safely in human subjects. It should also be noted that the absence of recognized human disease from the ubiquitous wild-type viruses related to Moloney murine leukemia virus provides further evidence that these agents are nonpathogenic in man (53).

HCT itself will involve significant risks. Our studies in mice, dogs, and baboons provide evidence that the surgical aspects of HCT can be performed safely. Our studies with transplantation of human hepatocytes into SCID mice indicate that these cells can be transplanted without toxicity or risk of infection to the subject. In addition, intensive efforts are essential to ensure that the process of hepatocellular harvest, cultivation, transduction, and transplantation is subjected to stringent quality control and quality assessment procedures as any other biologic product prepared for administration to humans would be.

Our preclinical data suggest that the HCT can be performed successfully. The ethical standards and federal regulations concerning clinical trials require that the relative risk of a clinical trial be "reasonably commensurate" with the patient's disease and conventional therapy (in this protocol orthotopic hepatic transplantation) (54-57). Thus, the patient selection criteria that have been established $(21)$ are essential in determining the relative risk of the proposed trial as described elsewhere.

Is it feasible? Most of the data described in this report address the issue of feasibility. The critical question is whether the provirus present in the small fraction of transduced and transplanted cells will be detectable in the recipient liver with existing assays. Figure 5 shows the fraction of cells that will contain the LNL6 provirus as a function of the transduction efficiency ( $\mathrm{x}$ axis, abscissa) and transplantation efficiency (y-axis, ordinate). The shaded region shows the expected frequency of provirus in transplanted organs based on these preclinical data. The curves show the threshold of sensitivity for assays capable of detecting the provirus in $10^{-3}, 10^{-4}$, and $10^{-5}$ cells. This graph illustrates that with a level of sensitivity of $10^{-5}$ it is reasonable to expect detection of proviral sequences in the study population.

This calculation also demonstrates the limitations of current methods for ex vivo gene delivery to the liver. For example, if successful gene therapy will require constitution of gene expression in $>1 \%$ of hepatic cells, significantly improved transduction or transplantation technologies will be required.

Is it necessary? We believe that it is important to establish the feasibility of HCT, the efficiency of engraftment, and the longev-

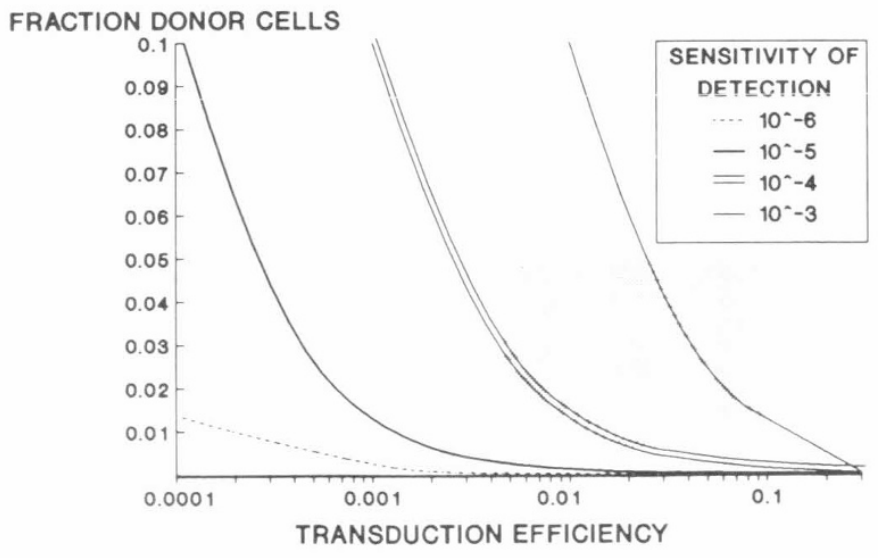

Range suggested by pre-clinical data

Fig. 5. Feasibility of detecting LNL6 provirus as a function of transduction and transplantation efficiency. The efficiency of transduction ( $\mathrm{x}$ axis) and efficiency of transplantation ( $y$-axis) determines the fraction of cells in the recipient that will contain the recombinant provirus. The range of transduction and transplantation efficiency suggested by preclinical data is shown by the shaded region. The range of detection is shown for assays with sensitivity of $10^{-4}, 10^{-5}$, and $10^{-6}$ with everything to the right of each curve being detectable. ity of transplanted cells in careful clinical trials. It is not obvious that any available animal models represent quantitatively appropriate models for assessing the efficiency of transduction and transplantation in human subjects, and it is likely that there will be variation in the efficiency of these processes in different individuals based on age, diagnosis, or other factors. Thus, we believe there is no substitute for clinical data concerning hepatocyte transduction and transplantation, in conjunction with continuing animal studies on optimization and safety, before $e x$ vivo gene therapy can be proposed with confidence.

This study was designed to assess methods for retrovirusmediated gene transfer in human subjects in a clinical situation in which the patient's well-being does not depend on the success of transduction or stable gene expression. This strategy was used previously by Rosenberg et al. (52), who used gene marking of tumor-infiltrating lymphocytes to establish the feasibility and safety of gene transfer in human subjects before proceeding with therapeutic trials of gene therapy. Marker gene studies have provided critical data concerning the efficiency of retroviral transduction, the persistence of the proviral sequences in vivo, and the level of transcription in human subjects and under clinical conditions (1-3). It is our expectation that gene-marking studies in human hepatocytes may similarly provide the foundation for future clinical trials of hepatic gene therapy.

Note added in proof: In December 1992, Dr. James Wilson of the University of Michigan reported to the Recombinant DNA Advisory Committee that an analogous protocol involving insertion of an LDL-receptor gene into the liver of patients with familial hypercholesterolemia had been performed successfully in one patient.

Acknowledgments. The authors thank the many individuals who contributed to development of a clinical protocol for hepatic gene transfer as part of the "Round Table on Hepatic Gene Therapy," particularly Dr. George Ferry, Dr. Ralph Feigin, Dr. William Klish, and Dr. Bert O'Malley for their input and encouragement.

\section{REFERENCES}

1. Anderson WF 1992 Human gene therapy. Science 256:808-813

2. Miller AD 1992 Human gene therapy comes of age. Nature $357: 1455-1460$

3. Ledley FD 1992 Are contemporary methods for somatic gene therapy suitable for clinical applications? Clin Invest Med 16:78-88

4. Ledley FD, Darlington G, Hahn T, Woo SLC 1987 Retroviral gene transfer into primary hepatocytes: implications for genetic therapy of liver specific functions. Proc Natl Acad Sci USA 84:5335-5339

5. Wolff JA, Yee JK, Skelly HF, Moores JC, Respess JG, Triedmann T, Leffert H 1987 Expression of retrovirally transduced genes in primary cultures of adult rat hepatocytes. Proc Natl Acad Sci USA 84:3344-3348

6. Wilson JM, Jefferson DM, Roy-Chowdhury J, Novikoff PM. Johnston DE, Mulligan RC 1988 Retrovirus-mediated transduction of adult hepatocytes. Proc Natl Acad Sci USA 85:3014-3018

7. Anderson KD, Thompson JA, DiPietro JM, Montgomery KT, Reid LM, Anderson WF 1989 Gene expression in implanted rat hepatocytes following retroviral-mediated gene transfer. Somatic Cell Mol Genet 1:215-227

8. Peng H. Armentano D. Graham L, Ledley FD. Woo SLC 1988 Retroviralmediated gene transfer and expression of human phenylalanine hydroxylase in primary mouse hepatocytes. Proc Natl Acad Sci USA 85:8146-8150

9. Ponder KP, Gupta S, Leland F, Darlington G. Finegold M, DeMayo J, Ledley FD. Roy-Chowdhury J. Woo SLC 1991 Mouse hepatocytes migrate to liver parenchyma and function indefinitely after intrasplenic transplantation. Proc Natl Acad Sci USA 88:1217-1221

10. Bumgardner GL. Fasola C, Sutherland DE 1988 Prospects for hepatocyte transplantation. Hepatology 8:1158-1161

11. Fuller BJ 1988 Transplantation of isolated hepatocytes. A review of current ideas. Hepatology 7:368-376

12. Gupta S, Roy-Chowdhury N, Jagtiani R. Gustin K. Aragona E. Shafritz DA Roy-Chowdhury J. Burk RD 1990 A novel system for transplantation of isolated hepatocytes utilizing HBsAg-producing transgenic donor cells. Transplantation 50:472-475

13. Gupta S. Aragona E. Vemuru RP. Bhagarva KK. Burk RD. Roy-Chowdhury J 1990 Permanent engraftment and function of hepatocytes delivered to the liver: implications for gene therapy and liver repopulation. Hepatology 14:144-149

14. Wilson JM, Roy-Chowdhury N, Grossman M, Wajsman R. Epstein A. Mulligan RC, Roy-Chowdhury J 1990 Temporary amelioration of hyperlipide- 
mia in low-density lipoprotein receptor deficient rabbits transplanted with genetically modified hepatocytes. Proc Nati Acad Sci USA 87:8437-8441

15. Roy-Chowdhury J, Grossman M, Gupta SJ, Roy-Chowdhury N, Baker Jr JR Wilson JM 1991 Long-term improvement of hypercholesterolemia after ex vivo gene therapy in LDLR-deficient rabbits. Science 254:1802-1805

16. Whitington PF, Balistreri WF 1991 Liver transplantation in pediatrics: indications, contraindications, and pretransplant management. J Pediatr 118:169-177

17. Sokal EM, Veyckemans F, de Ville de Goyet J, Molin D, Van Hoorebeeck N Alberti D, Buts JP, Rahier J, Van Obbergh L, Clapuyt P, Carlier M, Claus D, Latinne D, de Hemptinne D, Otte JB 1990 Liver transplantation in children less than 1 year of age. J Pediatr 117:205-210

18. Andrews WS, Wanek E, Fyock B, Gray S, Benser M 1989 Pediatric liver transplantation: a 3-year experience. J Pediatr Surg 24:77-82

19. Kalayoglu M. Stratta RJ, Sollinger HW, Hoffmann RM, D'Alessandro AM, Pirsch JD, Belzer FO 1989 Liver transplantation in infants and children. J Pediatr Surg 24:70-76

20. Otte JB, Yandza T, de Ville de Goyet J, Tan KC, Salizzoni M, de Hemptinne B 1988 Pediatric liver transplantation: report on 52 patients with a 2-year survival of $86 \%$. J Pediatr Surg 23:250-253

21. Makowka L, Falk RE, Rotstein LE, Falk JA, Nossal N, Langer B, Blendis LM. Phillips MJ 1980 Cellular transplantation in the treatment of experimental hepatic failure. Science 210:901-903

22. Sutherland D, Numata M, Matas A, Simmons R, Najarian J 1977 Hepatocellular transplantation in acute liver failure. Surgery 82:124-132

23. Minato M, Houssin D. Demma I, Morin J, Gigou M, Szeleky AM, Bismuth H 1984 Transplantation of hepatocytes for treatment of surgically induced acute hepatic failure in the rat. Eur J Surg Res 16:162-169

24. Demetriou A, Whiting JF, Felman D, Levenson SM, Roy-Chowdhury N, Moscioni AD, Kram M, Roy-Chowdhury J 1986 Replacement of liver functioning rats by transplantation of microcarrier-attached hepatocytes. Science 233:1190-1192

25. Sommer BG, Sutherland DE, Simmons RL, Najarian JS 1979 Hepatocellular transplantation for experimental acute liver failure in dogs. Surg Forum $30: 279-281$

26. Sommer BG, Sutherland DE, Matas AJ, Simmons RL, Najarian JS 1979 Hepatocellular transplantation for treatment of D-galactosamine-induced acute liver failure in rats. Transplant Proc 11:578-584

27. Benito JM, Cuervas-Mons-Martinez V, Colas A, Diaz M, Segovia-de-Arana JM 1989 Allotransplantation of hepatocytes into spleen prolongs survival and improves albumin levels in cirrhotic dogs. Transplant Proc 21:3520

28. Martin J, Cuervas-Mons V, Colas A, Diz M, Tormo J 1987 Intrasplenic hepatocellular transplantation as a hepatic support measure in cirrhotic dogs: preliminary results. Transplant Proc 19:3930-3931

29. Ledley FD, Woo SL, Ferry G, Whisennand HH, Brandt ML, Darlington GJ Demmler GJ, Finegold MJ, Pokorny WJ, Rosenblatt H, Schwartz P, Moen RL, Anderson WF 1991 Hepatocellular transplantation in acute hepatic failure and targeting genetic markers to hepatic cells. Hum Gene Ther 2:331358

30. Southard JH, val Guilik TM, Ametani MS 1990 Important components of the UW solution. Transplantation 49:251-257

31. Kalser SC, Hoofnagle JH 1990 Reports from the NIH DDDN. Human liver tissue for research. Gastroenterology 98:1086-1087

32. Berry MN, Friend DS 1969 High-yield preparation of isolated rat liver parenchymal cells: a biochemical and fine structural study. J Cell Biol 43:506-520

33. Lanford RE, Carey D, Estlack LE, Smith GC, Hay RV 1989 Analysis of plasma protein and lipoprotein synthesis in long-term primary cultures of baboon hepatocytes maintained in serum-free medium. In Vitro Cell Dev Biol 25:174-182

34. Adams RM, Soriano-Brucher HE, Wang M, Darlington GJ, Steffen D, Ledley FD 1992 Transduction of primary human hepatocytes with amphotropic and xenotrophic retroviral vectors. Proc Natl Acad Sci USA 89:8981-8985

35. Enat R, Jefferson DM, Ruiz Opazo N, Gatmaitan Z, Leinwand LA, Reid LM 1984 Hepatocyte proliferation in vitro: its dependence on the use of serumfree hormonally defined medium and substrata of extracellular matrix. Proc Natl Acad Sci USA 81:1411
36. Miller AD, Buttimore C 1986 Redesign of retrovirus packaging cell lines to avoid recombination leading to helper virus production. Mol Cell Biol 6:2895-2902

37. Miller AD, Rosman GJ 1989 Improved retroviral vectors for gene transfer and expression. BioTechniques 7:980-989

38. Morgan RA Cornetta K, Anderson WF 1990 Applications of the polvmerase chain reaction in retroviral-mediated gene transfer and the analysis of genemarked human TIL cells. Hum Gene Ther 1:135-149

39. Grossman M. Raper S, Wilson JM 1991 Towards liver-directed gene therapy: retrovirus-mediated gene transfer into human hepatocytes. Somatic Cell Mol Genet 17:601-607

40. Moscioni AD, Roy-Chowdhury J, Barbour R. Brown LL, Roy-Chowdhury N Competiello LS, Lahiri P. Demetriou AA 1989 Human liver cell transplantation. Prolonged function in athymic-Gunn and athymic-analbuminemic hybrid rats. Gastroenterology 96:1546-1551

41. Strom SC. Jirtle RL, Jones RS, Novicki DL. Rosenberg MR. Novotny A, Irons G, McLain JR, Michalopoulos G 1982 Isolation, culture, and transplantation of human hepatocytes. J Natl Cancer Inst 68:771-778

42. Soriano $H$, Lewis D, Legner $M$, Brandt $M$, Baley $P$, Darlington F. Finegold $M$ Ledley FD 1992 Use of Dil marked hepatocytes to demonstrate orthotopic. intrahepatic engraftment following hepatocellular transplantation. Transplantation 54:717-723

43. Ledley FD, Soriano HE, O’Malley Jr BW, Lewis D, Darlington GJ, Finegold M 1992 DiI as a marker for cellular transplantation into solid organs. BioTechniques 123:581-587

44. Kay MA, Baley P. Rothenberg S, Leland F. Fleming L. Ponder KP. Liu T Finegold M, Darlington G, Pokorny W, Woo SLC 1992 Expression of human alpha ${ }_{1}$-antitrypsin in dogs after autologous transplantation or retroviral transduced hepatocytes. Proc Natl Acad Sci USA 89:89-93

45. Ledley FD 1992 Somatic gene therapy in gastroenterology: approaches and applications. J Pediatr Gastroenterol Nutr 14:328-337

46. Ledley FD 1990 Clinical application of somatic gene therapy in inborn errors of metabolism. J Inherited Metab Dis 13:597-616

47. Recombinant DNA Advisory Committee 1992 Minutes of meeting May 3031, 1991. Hum Gene Ther 3:99-103

48. Cornetta K, Moen RC, Culver K. Morgan RA, McLachlin JR, Sturm S, Selegue J, London W, Blaese RM, Anderson WF 1990 Amphotropic murine leukemia retrovirus is not an acute pathogen for primates. Hum Gene Ther $1: 13-26$

49. Cornetta K, Morgan RA, Anderson WF 1991 Safety issues related to retroviral mediated gene transfer in humans. Hum Gene Ther 2:5-14

50. Culver KW, Morgan RA, Osborne WR, Lee RT, Lenschow D, Able C, Cornetta K, Anderson WF, Blaese RM 1990 In vivo expression and survival of genemodified T lymphocytes in rhesus monkeys. Hum Gene Ther 1:399-410

51. Kantoff PW, Kohn DB, Mitsuya H, Armentano D, Sieberg M. Zwiebel JA. Eglitis MA, McLachlin JR, Wiginton DA, Hutton JJ, Horowitz SD, Gilboa E, Blaese RM, Anderson WF 1986 Correlation of adenosine deaminase deficiency in cultured human $\mathrm{T}$ and $\mathrm{B}$ cells by retrovirus-mediated gene transfer. Proc Natl Acad Sci USA 83:6563-6567

52. Rosenberg SA, Aebersold P, Cornetta K, Kasid A, Morgan RA, Moen R, Karson EM. Lotze MT, Yang JC, Topalian SL, Merino MJ. Culver K, Miller AD, Blaese RM, Anderson WF 1990 Gene transfer into humans: immunotherapy of patients with advanced melanoma, using tumor-infiltrating lymphocytes modified by retroviral gene transduction. N Engl J Med 323:570578

53. Weiss R 1984 The search for human RNA tumor viruses. In: Weiss R, Teich N, Varmus H, Coffin J (eds) RNA Tumor Viruses. Cold Spring Harbor Laboratory, Cold Spring Harbor, New York, pp 1205-1281

54. Code of Federal Regulations 1983. Title 45, Part 46, Protection of Human Subjects (revised March 8, 1983)

55. Andrews LB 1987 Medical Genetics, a Legal Frontier. American Bar Foundation, Chicago

56. Ledley FD 1991 Clinical considerations in the design of protocols for somatic gene therapy. Hum Gene Ther 2:77-84

57. Ledley FD, Brody B, Kozinetz C, Mize M 1992 The challenge of follow-up for clinical trials of somatic gene therapy. Hum Gene Ther 3:657-664 